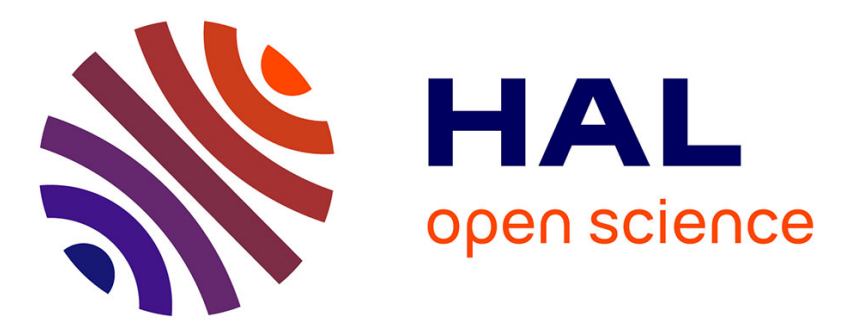

\title{
Microwave hydrothermal processing of Undaria pinnatifida for bioactive peptides
}

Julie Queffelec, N. Flórez-Fernández, H. Domínguez, M.D. Torres

\section{To cite this version:}

Julie Queffelec, N. Flórez-Fernández, H. Domínguez, M.D. Torres. Microwave hydrothermal processing of Undaria pinnatifida for bioactive peptides. Bioresource Technology, 2021, 342, pp.1-10/125882. 10.1016/j.biortech.2021.125882 . hal-03338922

\section{HAL Id: hal-03338922 https://imt-mines-albi.hal.science/hal-03338922}

Submitted on 28 Sep 2021

HAL is a multi-disciplinary open access archive for the deposit and dissemination of scientific research documents, whether they are published or not. The documents may come from teaching and research institutions in France or abroad, or from public or private research centers.
L'archive ouverte pluridisciplinaire HAL, est destinée au dépôt et à la diffusion de documents scientifiques de niveau recherche, publiés ou non, émanant des établissements d'enseignement et de recherche français ou étrangers, des laboratoires publics ou privés. 


\title{
Microwave hydrothermal processing of Undaria pinnatifida for bioactive peptides
}

\author{
J. Queffelec $^{\mathrm{a}, \mathrm{b}}$, N. Flórez-Fernández ${ }^{\mathrm{a}}$, H. Domínguez ${ }^{\mathrm{a}}$, M.D. Torres ${ }^{\mathrm{a}, *}$

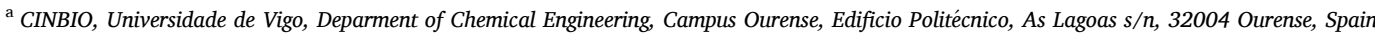 \\ ${ }^{\mathrm{b}}$ IMT Mines Albi, Allée des Sciences, 81000 Albi, France
}

- Hydrothermal extraction for $U$. pinnatifida was suitable to get functional fractions.

- The highest antioxidant features were identified above $200^{\circ} \mathrm{C}$.

- Alginate from $160{ }^{\circ} \mathrm{C}$ had satisfactory structural and viscoelasticity as commercial ones.

- Gelled matrices added with the residual solids showed adequate viscoelastic profiles.

- Antiproliferative activity was found for extracts from $220^{\circ} \mathrm{C}$ for A2780; HeLa 229.

Keywords:

Antioxidants

Biopolymer

Biorefinery

Green extraction

Hydrothermal extraction

\section{A B S T R A C T}

Microwave hydrothermal processing was employed to obtain valuable gelling or bioactive fractions from $U$. pinnatifida, assessing the processing conditions following a biorefinery concept. It was identified a relevant impact on the antioxidant properties, sulfate, protein and oligosaccharides content, with the highest values above $200{ }^{\circ} \mathrm{C}$, although the maximum in fucose was obtained at $160{ }^{\circ} \mathrm{C}$. The lowest temperature involved the highest minerals and sulfate content of the solid phases. Rheology indicated that hydrothermal treatment at $160{ }^{\circ} \mathrm{C}$ is adequate to extract alginates with structural and viscoelastic properties similar to those commercially available. The incorporation of the hydrothermal residual solids in the proposed alginate matrices favored the development of systems with potential non-food applications applications. Selected extracts, after an intensification stage using ultrasound, featured interesting biological activities for two human cancer cell lines (A2780; HeLa 229) with percentage of cellular inhibition $>83$ and 57\%, without positive effects on A549 and HCT-116.

\section{Introduction}

Consumed since the prehistoric times in Asia as sea vegetables, seaweeds are known for their richness in proteins, minerals, vitamins, phenolic compounds and polysaccharides which have multiple health benefits (Pereira, 2018; Kartik et al., 2021). In the last decades, the applications of algae are widening. They can be found in the food industry for their gelling and stabilizing properties, in agricultural applications as fertilizer or for land depollution and in biofuel production (Ferdouse et al., 2018; Khoo et al., 2019). However, one of the most relevant market in term of economic value could be in the pharmaceutical, nutraceuticals and cosmetics sectors..

In a context of global warming and dwindling of resources, the production systems and the ability to use resources material as a whole and to recycle byproducts have become a real concern. The concept of biorefinery illustrates well this idea of valorization of renewable resources avoiding any kind of waste and taking into account the life cycle of the product (Yuan and Macquarrie, 2015; Torres et al., 2019; Jung et al., 2013). Indeed, as defined by the International Energy Agency, the biorefinery is a sustainable way to convert a biomass into a value-added product (IEA, 2009). Seaweeds, due to their wide variety of compounds and their potential applications, may be an interesting biomass for biorefinery (Khoo et al., 2019).

Algae, which belongs to the Eukaryote domain, can be classified into 3 categories which vary, among other things, according to the pigments they produce. Chlorophyta known as green algae, Rhodophyta known as

* Corresponding author.

E-mail address: matorres@uvigo.es (M.D. Torres). 
red algae and Phaeophyceae also commonly called brown algae. While red and green algae depend on the Plantae kingdom, brown algae depend on the Chromista kingdom (Pereira., 2018; Fleurence and Levine, 2016). Namely, Undaria pinnatifida is a brown alga belonging to the Alariaceae family. As a brown alga, U. pinnatifida main photosynthetic pigments are fucoxanthin, chlorophylls "a", "c1" and "c2" in addition to other pigments such as $\beta$-carotene (Fleurence, 2016). Historically, $U$. pinnatifida is an Asian seaweed whose local name is Wakame but has been introduced in other areas such as Europe, New-Zeeland or South America. Its quick ability to colonize and spread made it classified as an invasive species which could potentially unbalanced marine ecosystems (Fung et al., 2013; Dellatorre et al., 2014).

Studies conducted on the early 21 century on seaweed have shown that a large number of natural bioactive compounds from algae could have application for drugs and cosmetics thanks to their antioxidant, antiviral agent, anti-inflammatory, anti-cancerous, anti-obesity or antiaging properties. Indeed, the marine environment exposes algae to high oxygen concentrations, sun and salt that cause the formation of oxidizing agents such as reactive oxygen species (Fung et al., 2013). This allows to figure out why algae have developed a defense system producing strong antioxidant compounds (Fleurence and Levine, 2016; Wang et al., 2017).

Undaria pinnatifida is no exception to this. Among its bioactive compounds, fucoidan (25-30\% of the alga dry weight), a sulfated polysaccharide usually made of L-Fucose units linked by (1-4) and (1-3) glycosidic bonds and sulfated at positions 2,3 and/or 4 . It can have a much more complicated main chain structure with other polysaccharides such as xylose or galactose (Rodriguez-Jasso et al., 2011; Kang et al., 2008; Gómez-Ordóñez et al., 2012). Its chemical composition and structure vary with the extraction techniques, the harvesting season, or the climatic conditions (Fleurence and Levine, 2016; Kartik et al., 2021). Fucoidan's antioxidant, anti-inflammatory, antiphotoaging, antiviral, anticellulite properties have been demonstrated in several studies which makes it an interesting bio compound. These effects are strongly linked to its structural properties (Gómez-Ordóñez et al., 2012).

Alginate is another polysaccharide found in the cell-wall of brown seaweed. It is composed of linear copolymers containing blocks of $(1 \rightarrow 4) \beta$-d-mannuronic acid $(\mathrm{M})$ and $(1 \rightarrow 4) \alpha$-l-guluronic acid (G) (Gomez et al., 2009). It can be qualified as a biomaterial which means "a material intended to interface with biological systems to evaluate, treat, augment or replace any tissue, organ or function of the body". Due to its biocompatibility, low toxicity and gelation properties, alginate has many applications in medicine and food industry (Lee and Mooney, 2012; Gómez-Ordóñez et al., 2012).

Traditionally, physical (mechanical grinding, centrifugation...), chemical (with organic solvent) and enzymatic techniques are used to extract compounds from seaweed, but these techniques have several drawbacks. They are time-consuming, the use of solvent might deteriorate some compounds and pollute the environment, and also require a high energy consumption. In this context, the development of novel green extraction methodologies has been required. Technologies as pulsed electric field, ultrasound-assisted extraction, sub- and supercritical fluid extraction, and microwave-assisted extraction (MAE) have been used inside of this concept. Experiments have shown that these technologies are faster, greener (lower energy and solvent consumption) and, besides, improve the extraction yields (Nadeeshani et al., 2021; Barba et al., 2015). Extraction technology as MAE allows a faster and more selective extraction of compounds using distillate water as solvent saving time, energy and resources (Rodriguez-Jasso et al., 2011; Kartik et al., 2021, Mirzadeh et al., 2020).

The main objective of this work is to extract valuable compounds from Undaria pinnatifida microwave assisted extraction as a greener and faster technique. The extracts were characterized for the bioactive compounds in the solid and the liquid phase obtained after filtration will be led in order to define the most appropriate processing conditions and potential further applications within a biorefinery approach..

\section{Materials and methods}

\subsection{Raw material}

Dried Undaria pinnatifida was purchased to Algamar (Pontevedra, Spain) and stored in darkness in sealed plastic bags at room temperature until further use. The ground material contained $8.93 \pm 0.06 \%$ (d.b.) moisture and $38.28 \pm 0.14 \%$ (d.b.) ash, both were determined gravimetrically. For moisture content, samples were introduced in a laboratory oven for $48 \mathrm{~h}$ at $105{ }^{\circ} \mathrm{C}$, in order to determine the ash content, a muffle was used at $575{ }^{\circ} \mathrm{C}$ for $6 \mathrm{~h}$.

\subsection{Microwave assisted hydrothermal treatment}

Microwave assisted extraction with subcritical water was applied to the ground seaweeds using an Anton Paar Microwave reactor Monowave 450 (Austria), equipped with an autosampler MAS 24. Microwave vials were filled with the ground algae and distilled water at a solid/liquid ratio 1:30 (w/w) as reported elsewhere (Balboa et al., 2013). Extraction experiments were performed at least by quintuplicate $(n=5)$, at different temperatures as followed: $120^{\circ} \mathrm{C}, 140{ }^{\circ} \mathrm{C}, 160{ }^{\circ} \mathrm{C}, 180^{\circ} \mathrm{C}$, $200{ }^{\circ} \mathrm{C}, 220^{\circ} \mathrm{C}$. The operation conditions (solid:liquid ratio and temperatures) were selected based on previous studies working with brown seaweeds, although using subcritical water extraction (Balboa et al., 2013). In all cases the samples were heated at the given temperature during $5 \mathrm{~min}$, at a rotation speed of $800 \mathrm{rpm}$ and at a power of $850 \mathrm{~W}$ and then were cooled until $50{ }^{\circ} \mathrm{C}$ after several preliminary tests and based on the results previously reported for other seaweeds (Ponthier et al., 2020). In order to separate the liquid and solid phases, vacuum filtration was performed. The solid phases, obtained after extraction, were dried in a laboratory oven at $40{ }^{\circ} \mathrm{C}$, milled and stored at room temperature in hermetic bags for further characterization. The alginate in the liquid fractions was precipitated using $\mathrm{CaCl}_{2}$ (Sigma-Aldrich, USA) at $1 \%(\mathrm{w} / \mathrm{w})$ and then recovered by vacuum filtration. The liquid phases were kept in the freezer at $-18{ }^{\circ} \mathrm{C}$ until further analysis.

\subsection{Ultrasound assisted posthydrolysis stage}

According to a previous work (Flórez-Fernández et al., 2017; Torres et al., 2021), liquid samples obtained by microwave hydrothermal treatments were further hydrolyzed, unfreezed, at $80^{\circ} \mathrm{C}$ during $30 \mathrm{~min}$ with ultrasonic assistance operating at $80 \mathrm{kHz}$ in an ultrasound water bath (Fisherbrand Scientific, FB11207). The treated samples were analyzed for antiproliferative properties.

\subsection{Analysis of the raw material and solid phase after extraction}

Both raw material and the solid residue remaining after microwave processing were characterized as follows. Moisture and ash content were gravimetrically measured, after drying in a laboratory oven at $105^{\circ} \mathrm{C}$ for $48 \mathrm{~h}$ and calcination in a furnace at $575^{\circ} \mathrm{C}$ for $6 \mathrm{~h}$, respectively. Protein content was quantified by nitrogen Kjeldahl method using 5.38 as conversion factor according to the recommendations given by Lourenco et al.(2002).

The carbon content was analyzed using an elemental analyzer (Thermo Flash EA 1112, Germany). The operation conditions were gas flow He $130 \mathrm{~mL} / \mathrm{min}$, gas flow reference $100 \mathrm{~mL} / \mathrm{min}$, oxygen flow $250 \mathrm{~mL} / \mathrm{min}$, the oxidation furnace temperature: $900{ }^{\circ} \mathrm{C}$ and the reduction furnace temperature: $680^{\circ} \mathrm{C}$, multiple analysis $6 \times 5 \mathrm{~mm}, 2.0 \mathrm{~m}$ (Cromlab, Spain) being the column temperature $50{ }^{\circ} \mathrm{C}$ and the chromatogram time: $420 \mathrm{~s}$. The pattern used was aspartic acid (Sigma, USA).

The content of minerals was determined by different methodologies. In all cases, an initial acidic digestion was required, where $0.3 \mathrm{~g}$ of ash were mixed with nitric acid $(10 \mathrm{~mL})$ and hydrogen peroxide $(1 \mathrm{~mL})$ using a Marsxpress (CEM). The operation conditions were $1600 \mathrm{~W}$ for $15 \mathrm{~min}$, holding at $200{ }^{\circ} \mathrm{C}$ for $10 \mathrm{~min}$. After that, atomic absorption spectroscopy 
was used for $\mathrm{Ca}, \mathrm{Fe}, \mathrm{Cu}$ and $\mathrm{Mg}$, atomic emission spectroscopy for $\mathrm{Na}$ and $\mathrm{K}$, using a spectrometer SpectrAA-220 Fast Sequential from Varian (USA). Cd was analyzed by ICP-MS (X Series, Thermo Scientific). The carbohydrate content was determined after acid hydrolysis of dried and milled samples (moisture $<10 \%$ ), which were mixed with sulfuric acid $(72 \%)$ and placed in test tubes in bath water at $30{ }^{\circ} \mathrm{C}$ for $60 \mathrm{~min}$. The hydrolysis of the samples continued in an autoclave for $60 \mathrm{~min}$ at $121^{\circ} \mathrm{C}$ with sulfuric acid at $4 \%$. A filtration step was required to separate the acid insoluble residue (AIR) and the liquid fraction. The liquid samples were filtered through $0.45 \mu \mathrm{m}$ filter and analyzed by HPLC (described below).

\subsection{Analysis of the soluble extracts}

\subsubsection{Phloroglucinol determination, analysis of phenolic compounds}

The measurement of phlorotannin (phenolic compound in brown seaweed) in the liquid fractions was carried out at least in triplicate by the spectrophotometric method of Koivikko (Koivikko et al., 2005). It is a modification of the Folin-Ciocalteu method (Singleton and Rossi, 1965). The standard curve was setting using $1 \mathrm{~mL}$ of phloroglucinol at concentrations from $0.030 \mathrm{~g} / \mathrm{L}$ to $0.005 \mathrm{~g} / \mathrm{L}$ (by triplicate). Subsequently, $1 \mathrm{~mL}$ of Folin-Ciocalteu ( $1 \mathrm{~N}$, diluted with distilled water) was added, and after $2 \mathrm{~mL}$ of $\mathrm{Na}_{2} \mathrm{CO}_{3}$ (Sigma Aldrich, USA) at $20 \%$ and vortex to mixture the sample and the reagents. The test tubes were left in the dark during $45 \mathrm{~min}$ before measuring the absorbance at $\lambda=730 \mathrm{~nm}$. The same process was done by triplicate with the liquid fractions of U. pinnatifida.

\subsubsection{Sulfate groups determination}

The sulfate content of the soluble extracts was determined spectrophotometrically, at least in triplicate, using the gelatin-barium chloride method (Dodgson, 1961). The gelatin-barium reagent was previously prepared mixing $0.5 \mathrm{~g}$ of gelatin (Scharlab, Spain) in $100 \mathrm{~mL}$ of hot water $\left(60-70{ }^{\circ} \mathrm{C}\right)$, after the total dissolution, the reagent was keeping at $4{ }^{\circ} \mathrm{C}$ for at least $6 \mathrm{~h}$ and then $0.5 \mathrm{~g}$ of $\mathrm{BaCl}_{2}$ (Scharlab, Spain) was added.

The standard curve was setting using $0.2 \mathrm{~mL}$ of $\mathrm{SO}_{4}{ }^{-}\left(\mathrm{K}_{2} \mathrm{SO}_{4}\right.$, Scharlab, Spain) solutions at concentrations from $2.25 \mathrm{~g} / \mathrm{L}$ to $0.25 \mathrm{~g} / \mathrm{L}$ mixed with $3.8 \mathrm{~mL}$ of trichloroacetic acid (Scharlab, Spain) at $4 \%$ and $1 \mathrm{~mL}$ of gelatin-barium reagent. After a $15 \mathrm{~min}$ of incubation at room temperature, the absorbance was measured at $\lambda=500 \mathrm{~nm}$. The same process was led using the soluble fractions.

\subsubsection{Soluble protein content}

The soluble protein content was determined at least in triplicate using the Bradford method (Bradford, 1976). In this spectrophotometric method, the standard curve was set using as pattern Bovine Serum Albumin (BSA) (Sigma Aldrich, USA) at concentrations from $1 \mu \mathrm{g} / \mathrm{mL}$ to $9 \mu \mathrm{g} / \mathrm{mL}$ mixed with Bradford Reagent according to the protocol supplied by Sigma-Aldrich. After an incubation time of $35 \mathrm{~min}$ at room temperature, the absorbance was measured at $\lambda=595 \mathrm{~nm}$. The same process was carried out using the soluble fractions obtained after the hydrothermal process.

\subsubsection{Antiradical capacity}

The antiradical capacity of the liquid phases was measured using the ABTS (2, 2'-azinobis (3-ethylbenzothiazoline-6-sulfonic acid) radical scavenging spectrophotometric method (Re et al., 1999). The reagent used was TEAC diluted with PBS in order to reach an absorbance between $0.700 \pm 0.1 \mathrm{~nm}$ at $\lambda=734 \mathrm{~nm}$. The standard curve was set adding $1 \mathrm{~mL}$ of the reagent to $10 \mu \mathrm{L}$ of Trolox (Acros organics, Slovakia) solutions at concentrations from $2 \mathrm{mM}$ to $0.10 \mathrm{mM}$. After stirring and $6 \mathrm{~min}$ of incubation in a water bath at $30^{\circ} \mathrm{C}$, the absorbance was measured at $\lambda=734 \mathrm{~nm}$. A control measure was made with distilled water. The same process was carried out using the soluble fractions.

\subsubsection{Oligosaccharide analysis by high Pressure liquid Chromatography}

In order to determinate the oligosaccharide fraction in the liquid samples, a posthydrolysis was performed using sulfuric acid at $4 \%$ for $20 \mathrm{~min}$ at $121{ }^{\circ} \mathrm{C}$ (autoclave, P-Selecta, Spain), the flasks were cooled until room temperature, and the liquids were filtrated through membranes $0.45 \mu \mathrm{m}$. The measures were performed by High-Pressure Liquid Chromatography (HPLC) using a 1100 series Agilent chromatograph provided by a refractive index detector. The column used was Aminex HPX87H column $(300 \times 7.8 \mathrm{~mm}$, BioRad, USA $)$ operating at $60{ }^{\circ} \mathrm{C}$ with $0.003 \mathrm{M} \mathrm{H}_{2} \mathrm{SO}_{4}$ (Sigma-Aldrich, USA) as mobile phase and the flow rate used was $0.6 \mathrm{~mL} / \mathrm{min}$.

\subsubsection{Molar mass distribution}

High-Performance Size Exclusion Chromatography (HPSEC) was used to assess the distribution of the molar mass of the liquid samples. This protocol was performed using an HPLC supplied by SuperMultipore PW-H column $(6 \mathrm{~mm} \times 15 \mathrm{~cm})$ with a guard column SuperMP (PW)-H $(4.6 \mathrm{~mm} \times 3.5 \mathrm{~cm}$ ), both from TSKgel by Tosoh Corporation (Japan). The operation conditions were: $40{ }^{\circ} \mathrm{C}$ and Milli-Q water as mobile phase $(0.4 \mathrm{~mL} / \mathrm{min})$, the detector used was a refractive index (RI) detector. The standards used were polyethylene oxide at different molecular weight from 23.6 to $786 \mathrm{kDa}$ were used as standards (Tosoh Corporation, Japan).

\subsection{Alginate fraction}

The alginate in the liquid fractions was precipitated using $\mathrm{CaCl}_{2}$ (, Sigma-Aldrich, USA) at $1 \%(\mathrm{w} / \mathrm{w})$ and then recovered by vacuum filtration and dried at $40{ }^{\circ} \mathrm{C}$ in a laboratory oven. Note here that the alginate was recovered only for liquid fractions obtained by MAE performed at $120{ }^{\circ} \mathrm{C}, 140{ }^{\circ} \mathrm{C}$ and $160{ }^{\circ} \mathrm{C}$, since negligible yields were identified at higher ones. The calcium alginate was converted to sodium alginate following a greener treatment explained in a previous study (Flórez-Fernández et al., 2019a). Briefly, lemon juice (up to pH 3) as a substitute for $\mathrm{HCl}$ typically employed in the well-known conventional method and $\mathrm{Na}_{2} \mathrm{CO}_{3}$ were incorporated to obtain the alginic acid sodium salt. This biopolymer was dehydrated in a vacuum oven at -0.8 bar and $40{ }^{\circ} \mathrm{C}$ for $48 \mathrm{~h}$, before being stored in airtight plastic containers until further analysis. Commercial alginate acid sodium salt from brown algae (Sigma-Aldrich, Germany) was used with comparative purposes.

\subsubsection{Structural features}

The freeze-dried sodium alginates were analyzed by Fourier transform infrared attenuated total reflectance (FTIR-ATR) and Proton Nuclear Magnetic Resonance $\left({ }^{1} \mathrm{H}\right.$ NMR). FTIR-ATR measurements were performed using a Nicolet 6700 infrared spectrophotometer (Thermo Scientific, USA). The biopolymers (around $2 \mathrm{mg}$ ) were mixed with $\mathrm{KBr}$ $(10 \mathrm{mg})$, pressed at 7 ton and dehydrated employing an infrared lamp for $30 \mathrm{~min}$. Monitoring of the FTIR-ATR spectra was conducted from 600 to $1800 \mathrm{~nm}$ at $30 \mathrm{scan} / \mathrm{min}$ using the OPUS-2.52 software (Opus Software Limited, UK). ${ }^{1} \mathrm{H}$ NMR was conducted on a Bruker ARX400 spectrometer (Bruker BioSpin GmbH, Germany). Spectra of the alginate solutions $(10 \mathrm{mg} / \mathrm{mL})$ were obtained employing deuterated water as solvent and 3-(trimethylsilyl)-L-propane sulfonic acid (Sigma-Aldrich, USA) as internal standard. Measurements were performed at $75{ }^{\circ} \mathrm{C}$ and $400 \mathrm{MHz}$. The signals of the anomeric protons of the mannuronic (M, $4.70 \mathrm{ppm}$ ) and guluronic ( $\mathrm{G}, 5.08, \mathrm{ppm}$ ) acids were identified, and the corresponding $\mathrm{M} / \mathrm{G}$ ratio calculated.

\subsubsection{Rheological features}

Aqueous solutions of tested sodium alginates $(1.0 \%, \mathrm{w} / \mathrm{w})$ were prepared at room temperature using distillated water as solvent. Then, $\mathrm{CaCl}_{2}(0.1 \mathrm{~mol} / \mathrm{L})$ was employed as gelling agent. The viscoelastic profile of the gelled biopolymer based matrices was determined on a controlled-stress rheometer (MCR302, Anton Paar, Germany) using a sand blasted parallel plate geometry (25 mm diameter, $1 \mathrm{~mm}$ gap). 
Before rheological testing, gelled matrices were sealed with light paraffin oil and were allowed to rest for $5 \mathrm{~min}$. Initially, stress sweeps (20 and $70^{\circ} \mathrm{C}, 1 \mathrm{~Hz}$ ) were performed to determine the linear viscoelastic region $(<54 \mathrm{~Pa})$ for the biopolymer gelled matrices. Afterwards, frequency sweeps from 0.1 to $10 \mathrm{~Hz}\left(25^{\circ} \mathrm{C}, 25 \mathrm{~Pa}\right)$ to define the viscoelastic gel properties (elastic modulus, G', and viscous modulus, G') were performed.

From the above analyzes, the alginate with the most adequate mechanical properties was selected to be used as gelling agent $(1 \%, \mathrm{w} / \mathrm{w})$ in the development of gelled matrices incorporated with the residual solids $(10 \%, \mathrm{w} / \mathrm{w})$ remaining after MAE treatment to make a comprehensive valuation of the algae. It should be indicated that all the residual solids were milled $<500 \mu \mathrm{m}$ before dehydrating at room temperature. The proposed matrices were cold stored for $24 \mathrm{~h}$ to ensure the full maturation of the gels. Then, their mechanical properties were assessed as aforementioned for the gelled alginate systems. In this case, the frequency sweeps were run within the linear viscoelastic region at $15 \mathrm{~Pa}$ and $25{ }^{\circ} \mathrm{C}$.

\subsection{Antiproliferative effect of the soluble extracts from $U$. Pinnatifida}

The assays were performed on four cell lines: lung (A549), human ovarian carcinoma (A2780), colon carcinoma (HCT-116) and human cervical cancer (HeLa229). Human carcinoma lung (A549) and cervical cancer (HeLa 229) cells were grown on culture with DMEM (Dulbeco Modified Eagle's Medium-low glucose) and, the ovarian cell lines (A2780) were cultured with RPMI 1640. The mediums were supplemented with Fetal Bovine Serum (FBS) at $10 \%$ and L-Glutamine at $2 \mathrm{mM}$. Colon carcinoma cells (HCT-116) were cultured in McCoy's 5a Medium Modified supplemented with 10\% FBS. All cell lines were incubated at $37{ }^{\circ} \mathrm{C}$ with atmosphere of $95 \%$ air $/ 5 \% \mathrm{CO}_{2}$.

MTT (3-[4,5-di- methylthiazol-2-yl]-2,-5 diphenyltetrazolium bromide) assay was performed to measure the inhibition of growth cell through metabolically active cells which can transform MTT to formazan crystals (Mosmann, 1983). A volume of $100 \mu \mathrm{L}$ of cells were seeded (96 wells plate) being the density 5,000 cells/well for A549,
4,000 cells/well for HeLa 229, 4,000 cells/well for A2780 and 5,000 cells/well for HCT-116, after an incubation of $24 \mathrm{~h}$ with the grown medium was performed. The extracts of $U$. pinnatifida were dissolved with distilled water at $1 \mathrm{mg} / \mathrm{mL}$ and incubated for $72 \mathrm{~h}$ (A549), for $48 \mathrm{~h}$ (HeLa 229), for $96 \mathrm{~h}$ (A2780) and $48 \mathrm{~h}$ (HCT-116). After this time of incubation, MTT reagent was added $(10 \mu \mathrm{L})$ and $4 \mathrm{~h}$ more of incubation. Finally, SDS (100 $\mu \mathrm{L}, 10 \%)$ dissolved in $\mathrm{HCl} 0.01 \mathrm{M}$ was also incorporate and incubated for $12-14 \mathrm{~h}$. After that, the cell plate was measured in Tecan M1000 infinite Pro (Austria) at $595 \mathrm{~nm}$.

\subsection{Statistical analysis}

All the analysis were carried out at least in triplicate, and the corresponding data evaluated by means of one-factor analysis of variance, ANOVA using the PASW Statistics v.22 software (IBM SPSS Statistics, New York, USA). In order to distinguish means with $95 \%$ confidence $(p<0.05)$, a post-hoc Scheffé test was made.

\section{Results and discussion}

\subsection{Microwave assisted hydrothermal treatment - Processing overview}

Fig. 1 shows the processing of the Undaria pinnatifida brown seaweed, a microwave hydrothermal extraction process was selected to recover biopolymers with potential applications. The extraction by microwave hydrothermal treatment allows a fast processing of the raw material when compared with conventional hydrothermal treatment, which means an energy saving. Another advantage of the microwave assisted extraction is the only use of distillate water as solvent, making it a more environmentally friendly technic with no toxic impact on compounds of interest compared to traditional ones. ¿Drawback: the fact that we are limited by the volume of the vial which makes it difficult to produce in large quantity?

Fig. 2 summarises the fundamental chemical properties of the seaweed used as raw material. The values obtained were consistent with those found in other works for U. pinnatifida (Peñalver et al., 2020). In

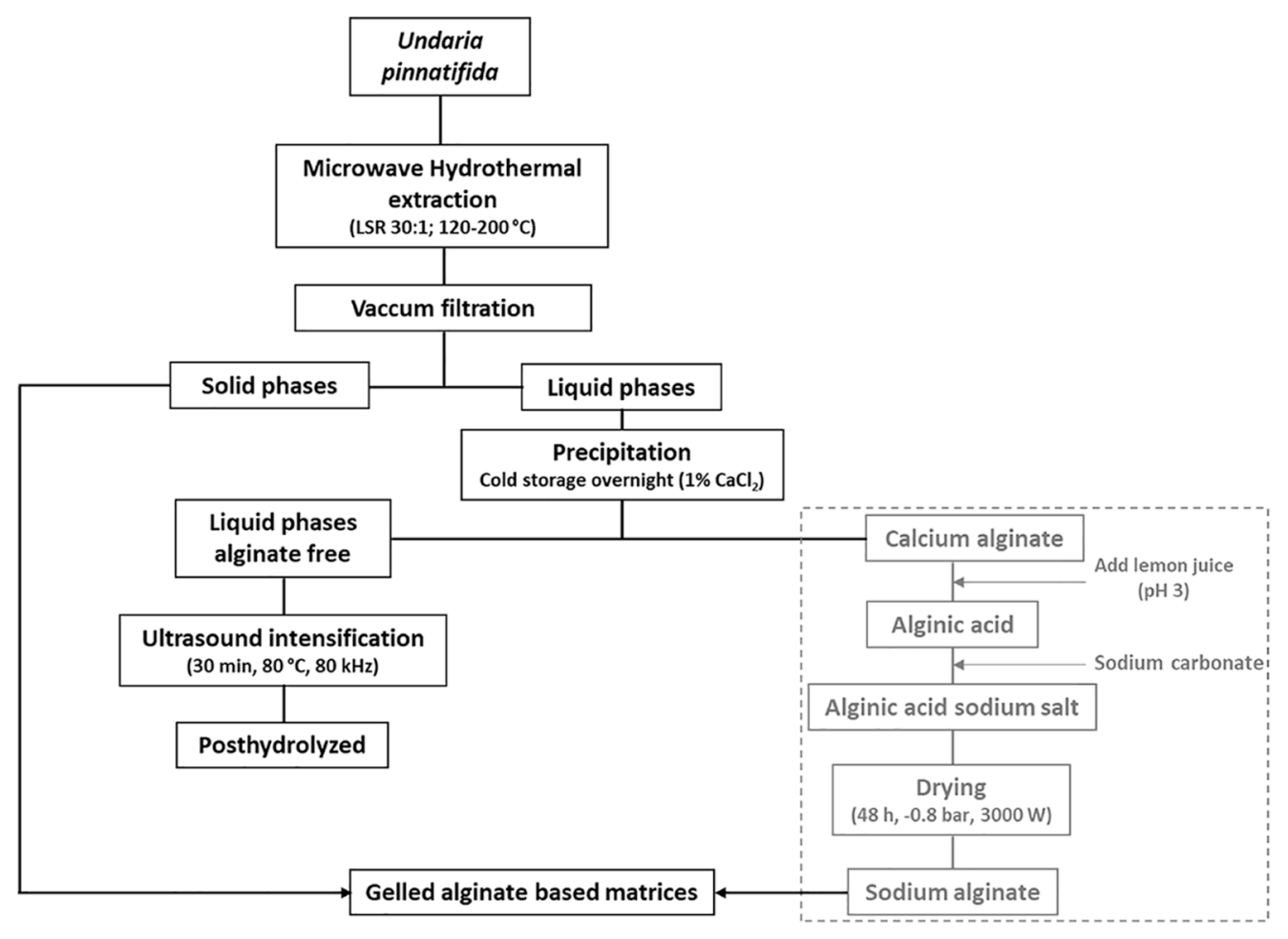

Fig. 1. General scheme of the microwave assisted hydrothermal extraction of biocompounds from Undaria pinnatifida brown seaweed. 


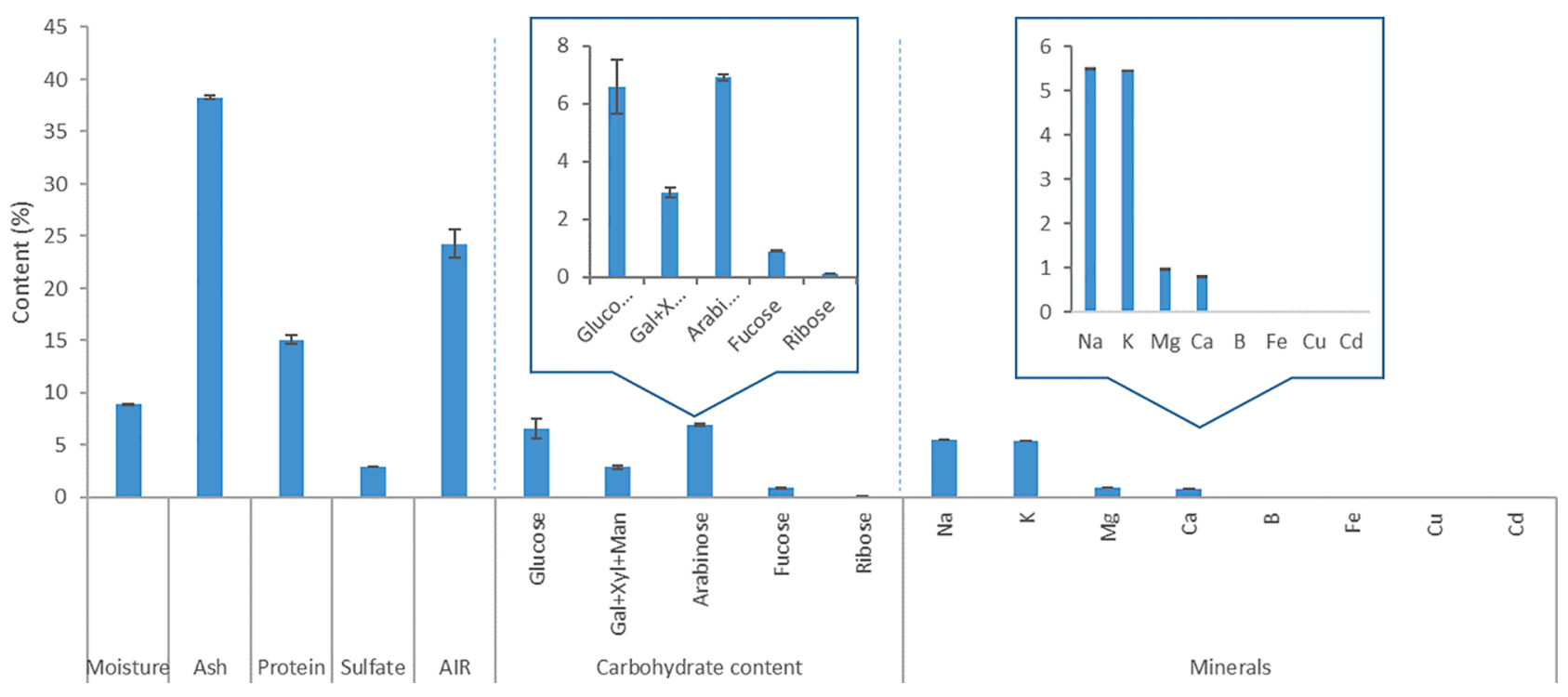

Fig. 2. Proximal composition of the brown seaweed Undaria pinnatifida.

comparison with other brown seaweeds, the value of protein was above the usual range (around 10\%). In this context, protein content value was similar to the values usually found for red seaweeds (around 20\%) (Peñalver et al., 2020). Other authors, Makkar et al. (2016) reported protein results around $12-14 \%$ for several brown seaweeds, however Holdt et al. (2011) observed higher values for Undaria (17-21\%). The content of ash for $U$. pinnatifida agreed with the results obtained for other Laminarales previously reported (Makkar et al., 2016), however this magnitude is bigger than other brown algae as $A$. nodosum. Regarding sulfate content, the obtained values were consistent with those previously reported for L. ochroleuca (1.5\%) (Flórez-Fernández et al., 2019b). Carbohydrate fraction of $U$. pinnatifida accounts around $17 \%$, being the major monosaccharides glucose and arabinose. GómezOrdóñez et al. (2010) found lower values (around 6.8\%) of total sugars for other Laminarales species, being glucose the major fraction. The main minerals in $U$. pinnatifida were sodium and potassium, followed by magnesium and calcium. The results obtained in this work were consistent with those previously reported (Circuncisão et al. 2018).

\subsection{Properties of the solid phase}

The solid phase after hydrothermal extraction was analysed. Table 1 show the results of the chemical composition of the solid fraction recovered by vacuum filtration. The values of the mineral and sulfate content decreased with temperature increase. In contrast, the protein content rose until reaching a maximum at $200{ }^{\circ} \mathrm{C}$. A similar behavior was observed for the ash content, decreasing with temperature rise. These results were in accordance with those obtained for Laminaria ochroleuca brown seaweed (Flórez-Fernández et al., 2019). In this work, these values were obtained for other extraction technology, also hydrothermal, namely subcritical water extraction. In this context, the advantage of using microwave assisted extraction was to achieve similar results with smaller operation time.

The high heating value (HHV) of the solid residue after microwave hydrothermal treatment was estimated following Eq. (1) (Trigueros et al., 2021),

$\mathrm{HHV}(\mathrm{kJ} / \mathrm{kg})=3.55 C^{2}-232 \mathrm{C}-2230 H+51.2 C \cdot \mathrm{H}+131 \mathrm{~N}+20600$

where $\mathrm{C}, \mathrm{H}$ and $\mathrm{N}$ are the carbon, hydrogen and nitrogen experimentally determined as indicated above. The estimated heating value increased with increasing hydrothermal temperature. These values are consistent with those previously reported for other seaweeds as G. sesquipedale (around $15,000 \mathrm{~kJ} / \mathrm{Kg}$ ) using subcritical water treatment.

Following a biorefinery approach, the potential of the residual solids as alternative agents in the development of gelled alginate based

Table 1

Influence of extraction temperature of the hydrothermal treatment carried out by microwave assisted on the composition of the solid fraction of $U$. pinnatifida brown seaweed and the estimated heating value (HHV).

\begin{tabular}{|c|c|c|c|c|c|c|}
\hline Content (\%) & $120^{\circ} \mathrm{C}$ & $140^{\circ} \mathrm{C}$ & $160^{\circ} \mathrm{C}$ & $180^{\circ} \mathrm{C}$ & $200{ }^{\circ} \mathrm{C}$ & $220^{\circ} \mathrm{C}$ \\
\hline Ash & $27.7 \pm 1.0$ & $19.8 \pm 0.8$ & $16.4 \pm 0.8$ & $9.3 \pm 1.5$ & $6.3 \pm 0.6$ & $4.0 \pm 1.9$ \\
\hline Protein & $18.6 \pm 1.6$ & $21.2 \pm 0.5$ & $24.4 \pm 0.3$ & $28.2 \pm 1.9$ & $28.7 \pm 2.2$ & $26.3 \pm 0.5$ \\
\hline Carbon & $31.4 \pm$ & $25.9 \pm$ & $39.7 \pm$ & $46.8 \pm$ & $51.1 \pm$ & $57.9 \pm$ \\
\hline Hydrogen & $4.0 \pm 0.1$ & $2.6 \pm 0.2$ & $3.7 \pm 0.2$ & $3.9 \pm 0.2$ & $3.7 \pm 0.2$ & $3.9 \pm 0.1$ \\
\hline Sulfate* & 1.52 & 2.21 & 1.87 & 1.30 & 0.97 & 0.59 \\
\hline \multicolumn{7}{|c|}{ Mineral $(\mathrm{g} / \mathrm{kg})^{* *}$} \\
\hline $\mathrm{K}$ & 36.5 & 32.9 & 21.9 & 10.5 & 7.8 & 6.8 \\
\hline $\mathrm{Na}$ & 34.6 & 30.2 & 20.1 & 9.2 & 7.1 & 6.2 \\
\hline $\mathrm{Ca}$ & 11.7 & 12.5 & 13.6 & 12.5 & 8.2 & 3.3 \\
\hline $\mathrm{Mg}$ & 8.9 & 8.2 & 6.4 & 3.1 & 2.5 & 1.5 \\
\hline $\mathrm{P}$ & 3.5 & 3.4 & 3.8 & 2.8 & 3.1 & 2.1 \\
\hline B (mg/Kg) & 65 & 52 & 41 & 21 & 22 & 28 \\
\hline $\mathrm{Cu}(\mathrm{mg} / \mathrm{Kg})$ & 37.8 & 18 & 15.1 & 16.7 & 12.8 & 14.6 \\
\hline $\mathrm{Hg}(\mathrm{mg} / \mathrm{Kg})$ & $<0.05$ & $<0.05$ & $<0.05$ & $<0.05$ & $<0.05$ & $<0.05$ \\
\hline $\mathrm{HHV}(\mathrm{kJ} / \mathrm{Kg})$ & 14,765 & 15,115 & 16,855 & 18,874 & 20,146 & 22,613 \\
\hline
\end{tabular}

\footnotetext{
* Standard deviations lower than 5\%.

S** Standard deviations were lower than $2.5 \%$.
} 
matrices was mechanically tested (see further details in rheological section).

\subsection{Analysis performed to the soluble extracts: Phloroglucinol, Sulfate, protein content and antioxidant activity}

Fig. $3 a$ and $3 b$ show the influence of the hydrothermal extraction process on the antioxidant activity and the content of phloroglucinol, respectively, in the liquid phases obtained from $U$. pinnatifida. In both cases, a parallel trend was identified, increasing with temperature increase and reaching a maximum value at $200{ }^{\circ} \mathrm{C}$. After this temperature, a slight drop was observed. Plaza et al. (2010) used subcritical water extraction at two temperatures to assess the antioxidant activity, similar trend is followed: the antioxidant activity increases while the temperature of extraction increases, similar behavior was observed for phenolic compounds. About the phenolic compounds, Magnusson et al. (2017) evaluated two processing techniques: MAE and conventional solid-liquid extraction, observing a great influence of the MAE temperature on the phloroglucinol content was observed, other parameters as solvent, solid:liquid ratio or reaction time were also evaluated.

On the other hand, Fig. 3c and 3d illustrate, respectively, the influence of temperature extraction using MAE as technology, on the protein and sulfate content measured in the liquid phases from the brown seaweed $U$. pinnatifida. In this case, the impact of the extraction temperature is much less progressive, the protein content increases dramatically at $160{ }^{\circ} \mathrm{C}$ and values until $220^{\circ} \mathrm{C}$ are quite close. For the

a)

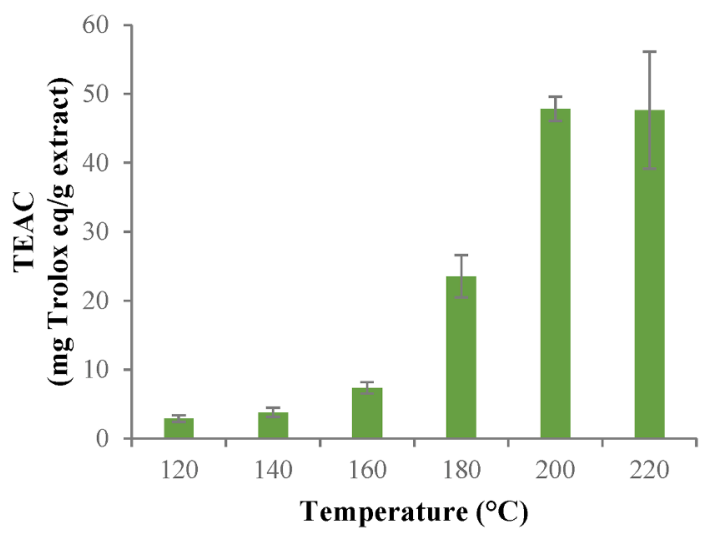

c)

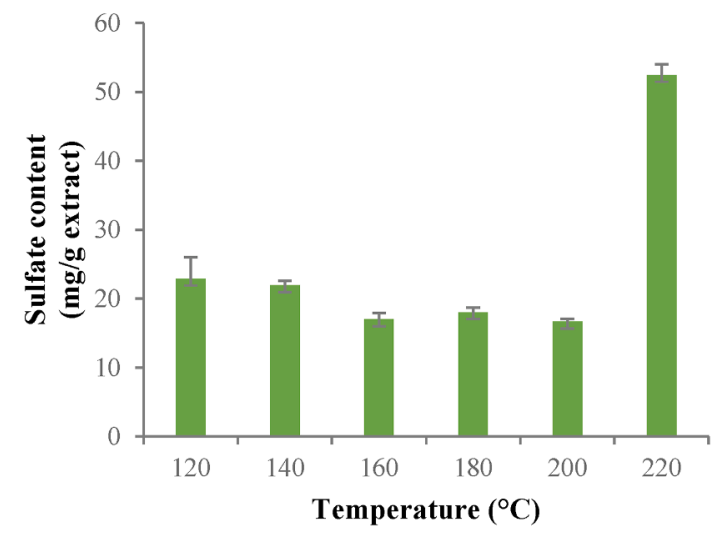

sulfate content, a great difference between the quantities in the liquid phase obtained at $220{ }^{\circ} \mathrm{C}$ increasing unexpectedly. This behavior could be explained by the action of the MAE, where the cell wall could release the sulfate solubilizing in the liquid phase. Lu et al. (2018) analyzing sulfate in five commercial fucoidan from $U$. pinnatifida being the maximum value $25.6 \%$, also other fucoidan was extracted from U. pinnatifida by hydrothermal processing (at $70{ }^{\circ} \mathrm{C}$, overnight) obtaining values smaller (20) than MAE in this work and requiring more time of extraction.

\subsection{Oligosaccharide content}

The effect of the autohydrolysis temperature on the oligosaccharide composition of the liquid phases of $U$. pinnatifida is presented in Fig. 4. The composition of the fractions obtained at different temperatures shown mainly four oligosaccharides: glucose, xylose, rhamnose and fucose, however, also note the presence of ribose for 160, 180 and $200{ }^{\circ} \mathrm{C}$. Although xylose and fucose are the majority oligosaccharides in each fraction, xylose content was maximized at $220{ }^{\circ} \mathrm{C}$ while that of fucose was the highest at $140^{\circ} \mathrm{C}$. Other authors, Mak et al (2013), also found as main monosaccharides fucose and xylose for $U$. pinnatifida brown seaweed, besides they quantify galactose, this difference could be explained by the fact that the composition of seaweeds varies greatly depending on harvesting season or the location of growth among other reasons. On the other hand, the degradation of oligosaccharides at high temperatures was observed in the literature (Balboa et al., 2013).

b)

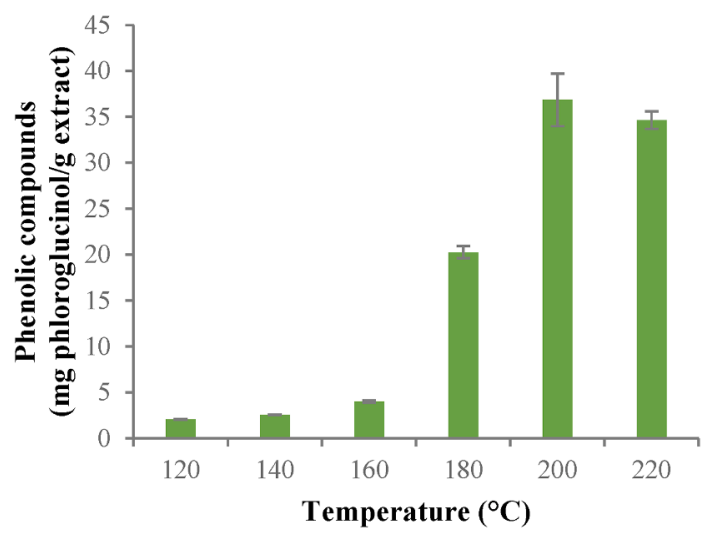

d)

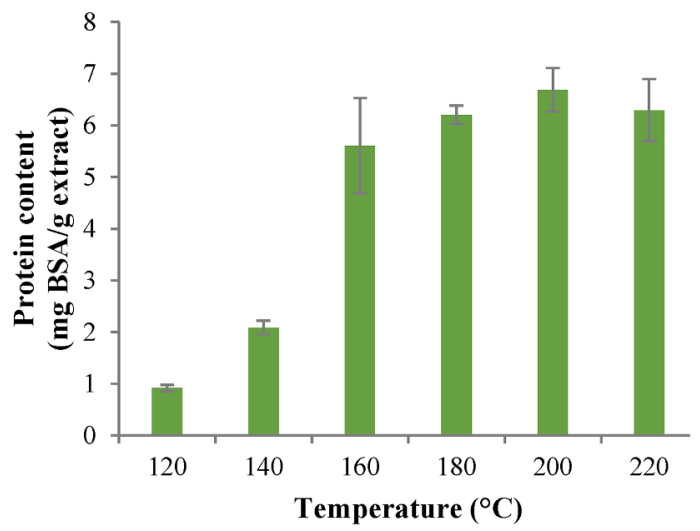

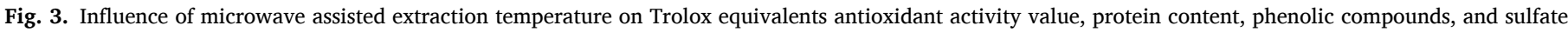
content of the liquid fractions. 


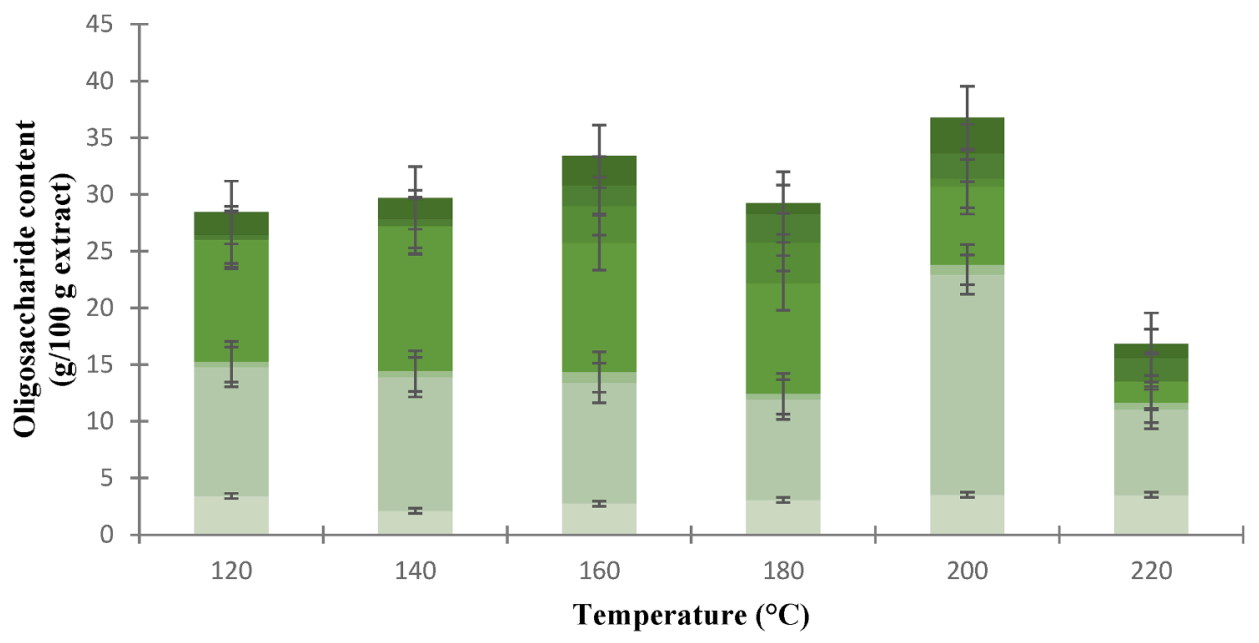

Glucose $\square$ Xylose $\square$ Rhamnose $\square$ Fucose $\square$ Ribose $\square$ Formic acid $\square$ Acetic acid

Fig. 4. Influence of microwave assisted extraction temperature on the oligosaccharide composition of the soluble extracts of $U$. pinnatifida.

\subsection{Molar mass distribution}

Profiles of the molar mass distribution of the extracts obtained by MAE at different temperatures were analyzed (see supplementary material). Different behavior was observed for the extracts obtained at 120 , 140 and $160{ }^{\circ} \mathrm{C}$ where two bands were clearly observed, for 120 and $140{ }^{\circ} \mathrm{C}$ the first peak was observed above $786 \mathrm{kDa}$ while $160{ }^{\circ} \mathrm{C}$ exhibited a peak around $786 \mathrm{kDa}$, the second band, was obtained for all the cases below $107 \mathrm{kDa}$. On the other hand, the extracts produced at higher temperatures $\left(180,200\right.$ and $220{ }^{\circ} \mathrm{C}$ ) display only one band. In this figure, the extracts of $U$. pinnatifida obtained at 180 and $220{ }^{\circ} \mathrm{C}$ shown a molecular weight below of $23.6 \mathrm{kDa}$ while the extract achieved at $200{ }^{\circ} \mathrm{C}$ exhibited a molar mass between 37.6 and $23.6 \mathrm{kDa}$. The distribution of the molar weight associated to the extracts obtained by MAE could be explained by the severity of the extraction method used. Other authors worked with other brown seaweed Ascophyllum nodosum also observed a similar behavior more temperature and more extraction time influence on molecular weight (Yuan and Macquarrie, 2015). On the other hand, Mateos-Aparicio et al. (2018) using as raw material Himanthalia elongata shown that different extraction strategies could be, also, affect in the response of the molar mass distribution.

\subsection{Alginate fraction}

The highest sodium alginate yield was obtained after hydrothermal treatment at $160{ }^{\circ} \mathrm{C}(4.5 \%)$, followed by $140{ }^{\circ} \mathrm{C}(9.2 \%)$ and $120{ }^{\circ} \mathrm{C}$ (19.8\%). The alginate yields were consistent with those previously reported for other Laminarales species (Belattmania et al., 2020). Negligible alginate yields $(<1.0 \%)$ were determined at the highest processing temperatures (from 180 to $220^{\circ} \mathrm{C}$ ).

\subsubsection{Structural features}

A comparative between a representative FTIR-ATR spectrum of sodium alginate obtained from $U$. pinnatifida after microwave treatment $\left(160^{\circ} \mathrm{C}\right)$ and those commercially available was performed (see supplementary material). Note here that similar spectra were observed for those alginates recovered after hydrothermal treatment at 120 or $140^{\circ} \mathrm{C}$ regardless of hydrothermal treatment. Broad intense bands found at $1590 \mathrm{~cm}^{-1}$ were assigned to $\mathrm{O}-\mathrm{C}-\mathrm{O}$ and $\mathrm{C}=\mathrm{O}$ asymmetric stretching vibrations of uronic acids. The intensity signals identified at $1409 \mathrm{~cm}^{-1}$ were attributed to deformation vibration of $\mathrm{C}-\mathrm{OH}$ groups, whereas those observed at wavenumbers about 1300 and $1025 \mathrm{~cm}^{-1}$ were attributed to the existence of sulfate groups and $\mathrm{C}-\mathrm{O}$ polysaccharides vibrations, respectively (Gómez-Ordóñez and Rupérez, 2011; Flórez-Fernández et al., 2019b). Lower intensity signals found at $890\left(\mathrm{~cm}^{-1}\right)$ and 813 $\left(\mathrm{cm}^{-1}\right.$ ) were related to the vibration of the $\alpha$-L-guluronic asymmetric ring and the $\beta$-mannuronic acid, respectively. These FTIR-ATR spectra agrees with those reported for the ground seaweed $U$. pinnatifida (Pereira and Ribeiro-Claro, 2014), the extracted alginate from the same seaweed (Zhang et al., 2020) and U. pinnatifida extracts using optimized conventional sequential extraction treatments (n-hexane, water:acetic acid (99:1), ethanol:water (1:1) or ethanol) (Ferreira et al., 2021).

Table 2 collects the block structural properties of tested sodium alginates $\left(120,140,160{ }^{\circ} \mathrm{C}\right)$ compared with its commercial counterparts. The well-known specific bands identified in the 1H NMR spectra (i.e. mannuronic (at $\sim 4.8 \mathrm{ppm}$ ) and guluronic (at $\sim 5.2 \mathrm{ppm}$ ) acid anomeric protons; guluronic acid (at $\sim 4.6 \mathrm{ppm}$ ); and the alternating blocks (at $\sim 4.9 \mathrm{ppm}$ )) as well as the corresponding areas were used for the quantitative determination of the mannuronic and guluronic acids (FM, FG), diad frequencies (FGG, FMM, FGM, FMG) and FM/ FG ratios (Pereira and Ribeiro-Claro, 2014).

No statistical differences were identified between the alginates extracted after microwave thermal treatment at 120 and $140{ }^{\circ} \mathrm{C}$, however significant differences were observed with those extracted after processing at $160{ }^{\circ} \mathrm{C}$. This last alginate exhibited lower $\mathrm{F}_{\mathrm{M}} / \mathrm{F}_{\mathrm{G}}$ values than those recovered at lower hydrothermal temperatures, involving lower values of $\mathrm{F}_{\mathrm{M}}$ and higher magnitude of $\mathrm{F}_{\mathrm{G}}$ when compared with gentler hydrothermal treatments. Note here that the sodium alginate obtained after hydrothermal treatment of $U$. pinnatifida at $160{ }^{\circ} \mathrm{C}$ showed the most similar properties to the commercial one, although with higher $\mathrm{F}_{\mathrm{M}} / \mathrm{F}_{\mathrm{G}}$ ratios. In all cases, $\mathrm{F}_{\mathrm{M}} / \mathrm{F}_{\mathrm{G}}$ magnitudes were $>1$ indicating higher content of mannuronic than guluronic acid blocks. These results are also consistent with those previously reported for U. pinnatifida (Skriptsova et al., 2004), where $\mathrm{F}_{\mathrm{M}} / \mathrm{F}_{\mathrm{G}}$ magnitudes were highly dependent on the collection season. This behavior also agrees

Table 2

Compositional block structural characteristics of sodium alginate extracted after hydrothermal treatment from $U$. pinnatifida.

\begin{tabular}{lllllll}
\hline Alginates & $\mathrm{F}_{\mathrm{M}} / \mathrm{F}_{\mathrm{G}}$ & $\mathrm{F}_{\mathrm{M}}$ & $\mathrm{F}_{\mathrm{G}}$ & $\mathrm{F}_{\mathrm{MM}}$ & $\mathrm{F}_{\mathrm{GG}}$ & $\mathrm{F}_{\mathrm{MG}}=\mathrm{F}_{\mathrm{GM}}$ \\
\hline Commercial & $1.70^{\mathrm{d}}$ & $0.63^{\mathrm{c}}$ & $0.37^{\mathrm{a}}$ & $0.44^{\mathrm{c}}$ & $0.18^{\mathrm{a}}$ & $0.19^{\mathrm{a}}$ \\
120 & $2.70^{\mathrm{a}}$ & $0.73^{\mathrm{a}}$ & $0.27^{\mathrm{c}}$ & $0.62^{\mathrm{a}}$ & $0.16^{\mathrm{c}}$ & $0.11^{\mathrm{c}}$ \\
140 & $2.57^{\mathrm{a}}$ & $0.72^{\mathrm{a}}$ & $0.28^{\mathrm{c}}$ & $0.60^{\mathrm{a}}$ & $0.16^{\mathrm{c}}$ & $0.12^{\mathrm{c}}$ \\
160 & $2.13^{\mathrm{c}}$ & $0.68^{\mathrm{b}}$ & $0.32^{\mathrm{b}}$ & $0.53^{\mathrm{b}}$ & $0.17^{\mathrm{a}}$ & $0.15^{\mathrm{b}}$ \\
\hline
\end{tabular}

All data exhibited standard deviations $<0.02$. Data values in a column with different superscript letters are significantly different at the $p \leq 0.05$ level. 
with those found for other similar Laminarales species (Belattmania et al., 2020). The obtained results suggest that alginates extracted after treatment at $160{ }^{\circ} \mathrm{C}$ will be able to develop stronger gelled matrices, since biopolymers with higher $\mathrm{F}_{\mathrm{G}}$ fractions provides higher viscosity with potential applications in the food and non-food fields (FlórezFernández et al., 2019a). It should be remarked that it is essential taking account not only the influence of the homopolymeric block structures, but also the alternating blocks. Low $\mathrm{F}_{\mathrm{GG}}$ and alternating blocks $\left(\mathrm{F}_{\mathrm{MG}}=\mathrm{F}_{\mathrm{GM}}\right)$, as well as intermediate $\mathrm{F}_{\mathrm{MM}}$ can promote the gelling availability of the biopolymer (Fenoradosoa et al., 2010; Belattmania et al., 2020).

\subsubsection{Rheological features}

The viscoelastic behavior of matrices prepared with sodium alginate $(1 \%, \mathrm{w} / \mathrm{w})$ extracted after microwave hydrothermal treatment at selected temperatures $\left(120-160{ }^{\circ} \mathrm{C}\right)$ is presented in Fig. 5. The mechanical spectrum of a commercial sodium alginate is also showed with comparative purposes. All systems exhibited typical gel performance with elastic modulus $>$ viscous modulus and both moduli practically invariant with frequency (Larotonda et al., 2016). Elastic modulus showed larger values (about 10 fold) than viscous modulus for all tested alginates. Gelled matrices developed with alginates from treatment at $160{ }^{\circ} \mathrm{C}$ presented higher viscoelasticity than those prepared with alginates from gentler treatments $\left(120-140{ }^{\circ} \mathrm{C}\right)$, where no notably differences were identified. The strongest gels (about 4 fold when compared with those from 120 to $140{ }^{\circ} \mathrm{C}$, and 2 fold compared to $160{ }^{\circ} \mathrm{C}$ ) were obtained with the commercial alginate. These results agree with those above explained for the alginate structural blocks with the highest $\mathrm{F}_{\mathrm{M}}$ / $\mathrm{F}_{\mathrm{G}}$ ratios, involving the strongest viscoelastic features of the corresponding gelled matrices. Even though, all tested alginates featured intermediate gel strength with viscoelastic magnitudes within those found in different field from biopolymer based films to gelling desserts (Larotonda et al., 2016; Torres et al., 2021).

According to the viscoelastic behavior, sodium alginate extracted after hydrothermal treatment at $160{ }^{\circ} \mathrm{C}$ was selected as gelling agent to develop alginate-based matrices incorporated with $10 \%$ of the solid residues remaining after processing at different temperatures. Fig. 6 shows an overview of the viscoelastic characteristics, in terms of $\mathrm{G}_{0}{ }^{\prime}$ and $\mathrm{G}_{0}{ }^{\prime \prime}$ of the gelled matrices at $1 \mathrm{~Hz}$, of the proposed systems containing the solid residues. Note here that in all cases gelled samples showed characteristic gel behavior with G'> G', (about 8-fold) over the tested frequency range. A drop on the viscoelastic properties of the alginate

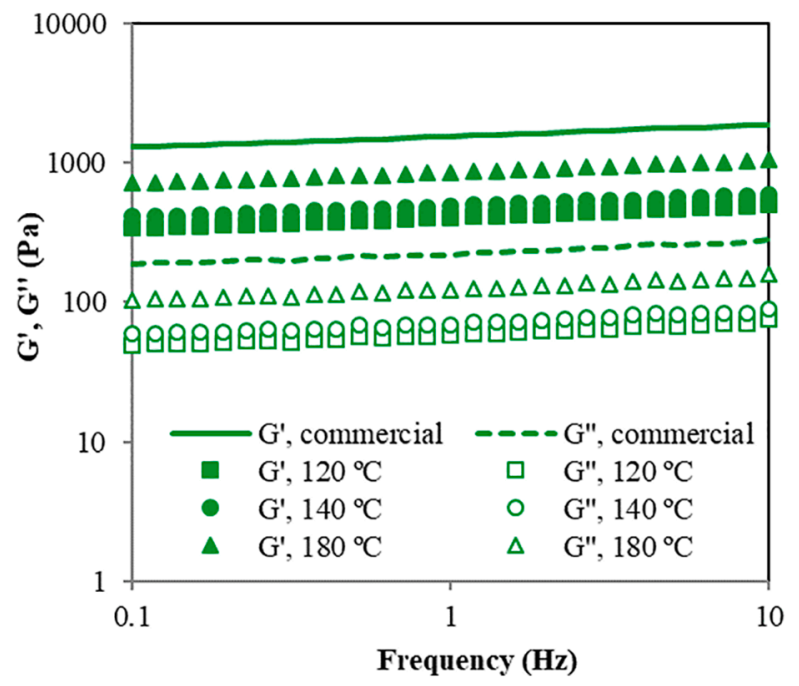

Fig. 5. Frequency sweeps of gelled matrices formulated with sodium alginate $(1 \%, w / w)$ recovered after microwave hydrothermal treatment of $U$. pinnatifida at different temperatures, and the commercial one.

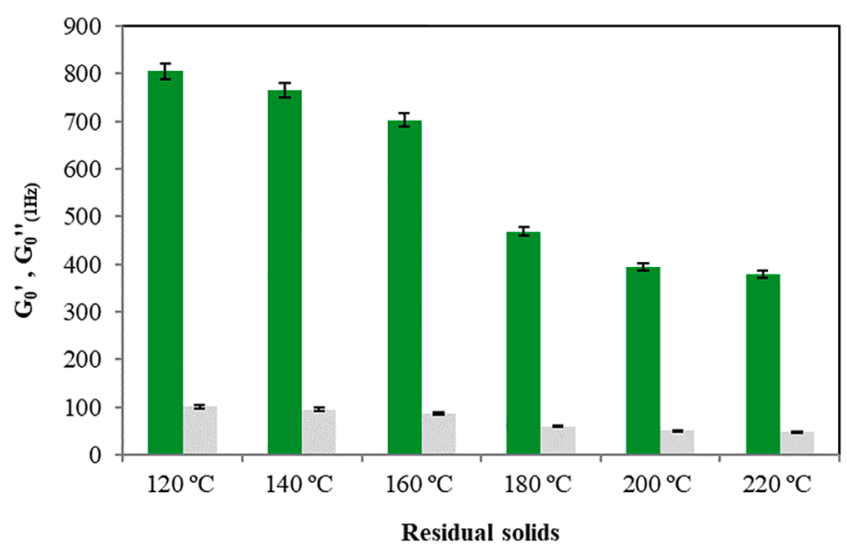

Fig. 6. Effect of residual solids remaining after microwave hydrothermal treatment of $U$. pinnatifida at different temperatures on the viscoelastic features of gelled matrices prepared with sodium alginate $(1 \%, \mathrm{w} / \mathrm{w})$ recovered at $160^{\circ} \mathrm{C}$.

gelled matrices was observed by the presence of solid residues, decreasing with increasing hydrothermal temperature. The weakest gels were found with the residues from $220^{\circ} \mathrm{C}$. This weakening of the gelling properties seems to be related with a water competition between alginate and incorporated solids, both highly hydrophilic (Torres et al., 2012). To sum up, rheological testing suggested that proposed gelled matrices formulated with residual solid fractions could be potential alternatives to prepare personal care goods as main ingredient for body scrubs or face masks (Moreira et al., 2012). It should be remarked that proposed gels did not exhibit water release after two weeks of cold storage.

\subsection{Antiproliferative effect}

The cell viability of the extracts from the brown seaweed $U$. pinnatifida were tested in four human cell lines, HeLa 229 (human cervical cancer cells), A2780 (human ovarian carcinoma cells), A549 (human lung cancer cells) and HCT-116 (human colon carcinoma cells). According to the characterization of the liquid phases obtained by MAE hydrothermal treatment, two extracts were selected. In this context, the temperatures chosen were $160^{\circ} \mathrm{C}$ and $220^{\circ} \mathrm{C}$. Molar mass distribution, FTIR results, fucose content, sulfate content, antioxidant activity and phenolic content were the parameters assessed to select these extracts. The results of the cell growth inhibition for the extract recovered at $160{ }^{\circ} \mathrm{C}$ testing HeLa 229 and A2780 cell lines were $37 \pm 2 \%$ and $49 \pm 3 \%$, respectively. Besides, for these cell lines, the extract obtained at $220{ }^{\circ} \mathrm{C}$ displays a IC ${ }_{50}$ of $0.76 \pm 0.03 \mathrm{mg} / \mathrm{mL}$ and $0.57 \pm 0.01 \mathrm{mg} / \mathrm{mL}$ corresponding to HeLa 229 and A2780, respectively. Etman et al. (2020) assayed the cell viability of fucoidan from the same raw material for human pancreatic cell line (PANC-1), the results exhibited an active fucoidan obtaining a $\mathrm{IC}_{50}$ at $53 \mu \mathrm{g} / \mathrm{mL}$. In our case, the results should be compared with extracts obtained from the raw material. In this context, two breast cancer cell lines (MCF-7 and MDA-MB-231) were tested to evaluate the cell viability, a limited effect on the growth of the tumoral cells was observed after 48, 72 and $96 \mathrm{~h}$ of incubation testing several concentrations of extract (Lu et al., 2018). In this work, two cell lines more were tested, A549 and HCT-116, in order to evaluate the cell viability. A slight effect was observed in the cancer cell growth inhibition, being the results for the extracts obtained at $160{ }^{\circ} \mathrm{C} 8 \pm 1 \%$ and $1 \pm 2 \%$, and for the extract obtained at $220^{\circ} \mathrm{C} 19 \pm 2 \%$ and $9 \pm 2 \%$ for A549 and HCT-116, respectively. This behavior was consistence with the results obtained by Lu et al. (2018). 


\section{Conclusions}

To conclude, microwave hydrothermal treatment of $U$. pinnatifida brown seaweed can be an adequate technology to recover soluble extracts with interesting antioxidant and biological properties without jeopardizing the viscoelastic features of the obtained sodium alginates. Following a biorefinery approach, the application of the solid residues in the development of novel gelled matrices using the extracted alginate with potential application in personal care products could be another advantage from the industrial point of view. Overall, above results allows an integral valorization of this edible brown seaweed that could be extended to other seaweed for potential food and non-food applications.

\section{Declaration of Competing Interest}

The authors declare that they have no known competing financial interests or personal relationships that could have appeared to influence the work reported in this paper.

\section{Acknowledgements}

Authors thank the financial support to the Ministry of Science, Innovation and Universities of Spain (CTM2015-68503R), and to the Xunta de Galicia (Centro singular de investigación de Galicia accreditation 2019-2022) and the European Union (European Regional Development Fund - ERDF) - (Ref. ED431G2019/06). M.D.T. acknowledges to the Ministry of Science, Innovation and Universities of Spain for her postdoctoral grants (RYC2018-024454-I) and to the Consellería de Cultura, Educación e Universidade da Xunta de Galicia (ED431F 2020/ 01). N.F.F. thanks the Xunta de Galicia for her postdoctoral grant (ED481B 2018/071). J.Q. thanks her ERASMUS + fellowship.

\section{Authors statement}

M.D.T. and H.D. conceived and planned the experiments. J.Q., N.F.F. and M.D.T. participated in the samples preparation, data analysis, interpretation of the results, and wrote the paper draft. N.F.F., M.D.T. and H.D. supervised the research work, contributed to the discussion of the data and revised the manuscript. All authors have read and agreed to the published version of the manuscript.

\section{Appendix A. Supplementary data}

Supplementary data to this article can be found online at https://doi. org/10.1016/j.biortech.2021.125882.

\section{References}

Balboa, E., Rivas, S., Moure, A., Domínguez, H., Parajó, J., 2013. Simultaneous extraction and depolymerization of fucoidan from Sargassum muticum in aqueous media. Mar. Drugs 11 (11), 4612-4627.

Barba, F.J., Grimi, N., Vorobiev, E., 2015. New Approaches for the Use of Nonconventional Cell Disruption Technologies to Extract Potential Food Additives and Nutraceuticals from Microalgae. Food Eng. Rev. 7 (1), 45-62.

Belattmania, Z., Kaidi, S., El Atouani, S., Katif, C., Bentiss, F., Jama, C., Reani, A., Sabour, B., Vasconcelos, V., 2020. Isolation and FTIR-ATR and 1H NMR characterization of alginates from the main alginophyte species of the atlantic coast of Morocco. Molecules 25 (18), 4335. https://doi.org/10.3390/molecules 25184335.

Bradford, M.M., 1976. A rapid and sensitive method for the quantitation of microgram quantities of protein utilizing the principle of protein-dye binding. Anal. Biochem. 72 (1-2), 248-254.

Circuncisão, A., Catarino, M., Cardoso, S., Silva, A., 2018. Minerals from macroalgae origin: Health benefits and risks for consumers. Mar. Drugs 16 (11), 400. https://doi $\operatorname{org} / 10.3390 / \mathrm{md} 16110400$.

Dellatorre, F., Amoroso, R., Saravia, J., Orensanz, L., 2014. Rapid expansion and potential range of the invasive kelp Undaria pinnatifida in the Southwest Atlantic. Aquat. Invasions 9 (4), 467-478.

Dodgson, K.S., 1961. Determination of inorganic sulphate in studies on the enzymic and non-enzymic hydrolysis of carbohydrate and other sulphate esters. Biochem. J. 78, 312-319.
Etman, S.M., Abdallah, O.Y., Elnaggar, Y.S.R., 2020. Novel fucoidan based bioactive targeted nanoparticles from Undaria pinnatifida for treatment of pancreatic cancer. Int. J. Biol. Macromol. 145, 390-401.

Flórez-Fernández, N., Domínguez, H., Torres, M.D., 2019a. A green approach for alginate extraction from Sargassum muticum brown seaweed using ultrasound-assisted technique. Int. J. Biol. Macromol. 124, 451-459.

Flórez-Fernández, N., Torres, M.D., González-Muñoz, M.J., Domínguez, H., 2019. Recovery of bioactive and gelling extracts from edible brown seaweed Laminaria ochroleuca by non-isothermal autohydrolysis. Food Chem. 277, 353-361.

Fenoradosoa, T.A., Ali, G., Delattre, C., Laroche, C., Petit, E., Wadouachi, A., Michaud, P., 2010. Extraction and characterization of an alginate from the brown seaweed Sargassum turbinarioides Grunow. J. Appl. Phycol. 22 (2), 131-137.

Ferdouse, F., Holdt, S.L., Smith, R., Murúa, P., Yang, Z., 2018. The global status of seaweed production, trade and utilization. GLOBEFISH Research Programme 124.

Ferreira, C.A.M., Félix, R., Félix, C., Januário, A.P., Alves, N., Novais, S.C., Dias, J.R. Lemos, M.F.L., 2021. A biorefinery approach to the biomass of the seaweed Undaria pinnatifida (Harvey suringar, 1873): Obtaining phlorotannins-enriched extracts for wound healing. Biomolecules 11 (3), 461. https://doi.org/10.3390/biom11030461.

Fleurence, J., Levine, I., 2016. Seaweed in Health and Disease Prevention. Elsevier Science. Web, San Diego.

Fung, A., Hamid, N., Lu, J., 2013. Fucoxanthin content and antioxidant properties of Undaria pinnatifida. Food Chem. 136 (2), 1055-1062.

Gomez, C.G., Pérez Lambrecht, M.V., Lozano, J.E., Rinaudo, M., Villar, M.A., 2009. Influence of the extraction-purification conditions on final properties of alginates obtained from brown algae (Macrocystis pyrifera). Int. J. Biol. Macromol. 44 (4), 365-371.

Gómez-Ordóñez, E., Rupérez, P., 2011. FTIR-ATR spectroscopy as a tool for polysaccharide identification in edible brown and red seaweeds. Food Hydrocoll. 25 (6), 1514-1520.

Gómez-Ordóñez, E., Jiménez-Escrig, A., Rupérez, P., 2012. Molecular weight distribution of polysaccharides from edible seaweeds by high-performance size-exclusion chromatography (HPSEC). Talanta 93, 153-159.

Makkar, H.P.S., Tran, G., Heuzé, V., Giger-Reverdin, S., Lessire, M., Lebas, F., Ankers, P., 2016. Seaweeds for livestock diets: A review. Anim. Feed Sci. Tech. 212, 1-17.

IEA (International Energy Agency), (2009). IEA Bioenergy Task 42 Biorefinery. Available from: < https://task42.ieabioenergy.com/>.

Jung, K.A., Lim, S.-R., Kim, Y., Park, J.M., 2013. Potentials of macroalgae as feedstocks for biorefinery. Bioresour. Technol. 135, 182-190.

Kang, K.S., Kim, I.D., Kwon, R.H., Ha, B.J., 2008. Undaria pinnatifida fucoidan extract protects against $\mathrm{CCl}_{4}$-induced oxidative stress. Biotechnol. Bioprocess. Eng. 13 (2), 168-173.

Kartik, A., Akhil, D., Lakshmi, D., Panchamoorthy Gopinath, K., Arun, J., Sivaramakrishnan, R., Pugazhendhi, A., 2021. A critical review on production of biopolymers from algae biomass and their applications. Bioresour. Technol. 329, 124868. https://doi.org/10.1016/j.biortech.2021.124868.

Koivikko, R., Loponen, J., Honkanen, T., Jormalainen, V., 2005. Contents of soluble, cellwall-bound and exuded phlorotannins in the brown alga Fucus vesiculosus, with implications on their ecological functions. J. Chem. Ecol. 31 (1), 195-212.

Khoo, C.G., Dasan, Y.K., Lam, M.K., Lee, K.T., 2019. Algae biorefinery: Review on a broad spectrum of downstream processes and products. Bioresour. Technol. 292, 121964. https://doi.org/10.1016/j.biortech.2019.121964.

Lee, K.Y., Mooney, D.J., 2012. Alginate: Properties and biomedical applications. Prog. Polym. Sci. 37 (1), 106-126.

Lourenco, S.O., Barbarino, E., De-Paula, J.C., Pereira, L.O.d.S., Marquez, U.M.L., 2002. Amino acid composition, protein content and calculation of nitrogen-to-protein conversion factors for 19 tropical seaweeds. Phycol. Res. 50 (3), 233-241.

Lu, J., Shi, K., Chen, S., Wang, J., Hassouna, A., White, L., Merien, F., Xie, M., Kong, Q., Li, J., Ying, T., White, W., Nie, S., 2018. Fucoidan Extracted from the New Zealand Undaria pinnatifida - Physicochemical Comparison against Five Other Fucoidans: Unique Low Molecular Weight Fraction Bioactivity in Breast Cancer Cell Lines. Mar. Drugs 16 (12), 461. https://doi.org/10.3390/md16120461.

Magnusson, M., Yuen, A.K.L., Zhang, R., Wright, J.T., Taylor, R.B., Maschmeyer, T., de Nys, R., 2017. A comparative assessment of microwave assisted (MAE) and conventional solid-liquid (SLE) techniques for the extraction of phloroglucinol from brown seaweed. Algal Res. 23, 28-36.

Mak, W., Hamid, N., Liu, T., Lu, J., White, W.L., 2013. Fucoidan from New Zealand Undaria pinnatifida: Monthly variations and determination of antioxidant activities. Carbohydr. Polym. 95 (1), 606-614.

Mateos-Aparicio, I., Martera, G., Goñi, I., Villanueva-Suárez, M.-J., Redondo-Cuenca, A., 2018. Chemical structure and molecular weight influence the in vitro fermentability of polysaccharide extracts from the edible seaweeds Himathalia elongata and Gigartina pistillata. Food Hydrocoll. 83, 348-354.

Mirzadeh, M., Arianejad, M.R., Khedmat, L., 2020. Antioxidant, antiradical, and antimicrobial activities of polysaccharides obtained by microwave-assisted extraction method: A review. Carbohydr. Polym. 229, 115421. https://doi.org/ 10.1016/j.carbpol.2019.115421.

Mosmann, T., 1983. Rapid colorimetric assay for cellular growth and survival: Application to proliferation and cytotoxicity assays. J. Immunol. Methods 65 (1-2), 55-63.

Nadeeshani, H., Hassouna, A., Lu, J., 2021. Proteins extracted from seaweed Undaria pinnatifida and their potential uses as foods and nutraceuticals. Crit. Rev. Food. Sci. Nutr. 11, 1-17.

Plaza, M., Amigo-Benavent, M., del Castillo, M.D., Ibáñez, E., Herrero, M., 2010. Facts about the formation of new antioxidants in natural samples after subcritical water extraction. Food Res. Int. 43 (10), 2341-2348. 
Peñalver, R., Lorenzo, J.M., Ros, G., Amarowicz, R., Pateiro, M., Nieto, G., 2020. Seaweeds as a Functional Ingredient for a Healthy Diet. Mar. Drugs 18 (6), 301. https://doi.org/10.3390/md18060301.

Pereira, L., Ribeiro-Claro, P.J.A., 2014. Analysis by vibrational spectroscopy of seaweed with potential use in food, pharmaceutical and cosmetic industries. Biodiversity, Taxonomy, Environmental Assessment, and Biotechnology, Marine Algae, pp. 228-250.

Pereira, L., 2018. Seaweeds as Source of Bioactive Substances and Skin Care. Cosmetics $5,68$.

Ponthier, E., Domínguez, H., Torres, M.D., 2020. The microwave assisted extraction sway on the features of antioxidant compounds and gelling biopolymers from Mastocarpus stellatus. Algal Res 51, 102081. https://doi.org/10.1016/j.algal.2020.102081.

Re, R., Pellegrini, N., Proteggente, A., Pannala, A., Yang, M., Rice-Evans, C., 1999 Antioxidant activity applying an improved ABTS radical cation decolorization assay. Free Radic. Biol. Med. 26 (9-10), 1231-1237.

Rodriguez-Jasso, R.M., Mussatto, S.I., Pastrana, L., Aguilar, C.N., Teixeira, J.A., 2011 Microwave-assisted extraction of sulfated polysaccharides (fucoidan) from brown seaweed. Carbohydr. Polym. 86 (3), 1137-1144.

Singleton, V.L., Rossi, J.A., 1965. Colorimetry of total phenolics with phosphomolybdicphosphotungstic acid reagents. American Journal of Enology and Viticulture 16, 144-158.

Skriptsova, A., Khomenko, V., Isakov, V., 2004. Seasonal changes in growth rate, morphology and alginate content in Undaria pinnatifida at the northern limit in the Sea of Japan (Russia). J. Appl. Phycol. 16 (1), 17-21.
Torres, M.D., Kraan, S., Domínguez, H., 2019. Seaweed biorefinery. Rev. Environ. Sci. Biotechnol. 18 (2), 335-388.

Trigueros, E., Sanz, M.T., Alonso-Riaño, P., Beltrán, S., Ramos, C., Melgosa, R., 2021. Recovery of the protein fraction with high antioxidant activity from red seaweed industrial solid residue after agar extraction by subcritical water treatment. J. Appl. Phycol. 33 (2), 1181-1194.

Wang, H.-M., Li, X.-C., Lee, D.-J., Chang, J.-S., 2017. Potential biomedical applications of marine algae. Bioresour. Technol. 244, 1407-1415.

Yuan, Y., Macquarrie, D.J., 2015. Microwave assisted step-by-step process for the production of fucoidan, alginate sodium, sugars and biochar from Ascophyllum nodosum through a biorefinery concept. Bioresour. Technol. 198, 819-827.

Zhang, R., Yuen, A.K.L., de Nys, R., Masters, A.F., Maschmeyer, T., 2020. Step by step extraction of bio-actives from the brown seaweeds, Carpophyllum flexuosum, Carpophyllum plumosum, Ecklonia radiata and Undaria pinnatifida. Algal Res. 52, 102092. https://doi.org/10.1016/j.algal.2020.102092.

Flórez-Fernández, N., López-García, M., González-Muñoz, M.J., Vilariño, J.M.L. Domínguez, H., 2017. Ultrasound-assisted extraction of fucoidan from Sargassum muticum. Journal of Applied Phycology 29 (3), 1553-1561.

Larotonda, F.D.S., Torres, M.D., Gonçalves, M.P., Sereno, A.M., Hilliou, L. Hybrid carrageenan-based formulations for edible film preparation: Benchmarking with kappa carrageenan (2016) Journal of Applied Polymer Science, 133 (2), art. no. 42263,.

Moreira, R., Chenlo, F., Torres, M.D., 2012. Effect of shortenings on the rheology of gluten-free doughs: Study of chestnut flour with chia flour, olive and sunflower oils. Journal of Texture Studies 43 (5), 375-383. 